\title{
PENGETAHUAN REMAJA DAN MOTIVASI GURU DENGAN PERILAKU SEKS BEBAS DI SMA
}

\author{
Ashriady ${ }^{1}$, Rosdiana Ufi ${ }^{2}$ \\ ${ }^{1}$ Jurusan Kebidanan Poltekkes Kemenkes Mamuju \\ ${ }^{2}$ Fakultas Kesehatan Masyarakat Universitas Dayanu Ikhsanuddin
}

\begin{abstract}
Free sex could threaten the future of adolescents, especially in the field of education. Almost all of the schools that the average level of high school (High School) in particular SMAN 4 Baubau admitted annually forced to pull out with pupils from the school because it was considered guilty. The problem of sex leading to pregnancy outside marriage and sometimes lead to abortion. The purpose of this study was aimed to determine the relationship of sex behavior in adolescents on the motivation of teachers at SMAN 4 Baubau. This research is a quantitative research with cross sectional study design. The sample in this study is 88 samples. The sampling technique used was a systematic random sampling. Data processing using the statistical test Chi Square test with a confidence level of 95\% (value $=0.05$ ). Based on the results it can be concluded that there is a relationship between knowledge students free sex $\left(X^{2}=10.728, p=0.001\right)$, there is a correlation between students with the knowledge of free sex $\left(\mathrm{X}^{2}=138.692, \mathrm{p}=0.000\right)$. It is suggested that students can improve their knowledge about sex, abiding by the religious level, by searching for a good and accurate information and can choose which friends so as not to affect the behavior of free sex. Teachers can motivate by providing knowledge about free sex, and the understanding of religion as well as provide good information and be responsible so that students are not wrong in getting information that may affect student behavior.
\end{abstract}

Keyword: knowledge of students, teacher motivation, free sex.

\section{PENDAHULUAN}

WHO (World Health Organization) memperkirakan dengan rata-rata $100 \%$ seluruh remaja yang ada di dunia, diperkirakan $47 \%$ nya telah terlibat dalam perilaku seks bebas. Angka ini juga sangat berkaitan dengan tingginya jumlah angka penderita HIV/AIDS (Human Immunodeviciency Virus/Aquared Immuno Deficiency Virus) yang terus menerus meningkat tiap tahunnya. Terbukti pada Tahun 2002 jumlah penderita diperkirakan 90.000 hingga 160.000an kasus.Angka ini semakin meningkat di tahun 2006, antara 169.000 hingga 216.000 (Sarlito, 2011)

Remaja merupakan masa peralihan antara tahap anak dan dewasa yang jangka waktunya berbeda-beda tergantung faktor sosial dan budaya. Cirinya adalah alat reproduksi mulai berfungsi, libido mulai muncul, intelegency mencapai puncak perkembangannya, emosi sangat labil, kesetiakawanan yang kuat terhadap teman sebaya dan belum menikah. Kondisi yang belum menikah menyebabkan remaja secara sosial budaya termasuk agama dianggap belum berhak atas informasi dan edukasi apalagi pelayanan medis untuk kesehatan reproduksi. Terjerumusnya remaja ke dalam dunia hubungan sosial yang luas maka mereka tidak saja harus mulai adaptasi dengan normaperilaku sosial tetapi juga sekaligus dihadapkan dengan munculnya perasaan dan keinginan seksual (Subhakti, 2009).

Menurut di zaman era globalisasi ini ilmu pengetahuan dan teknologi berkembang pesat. Para orang tua dan remaja menyadari akan pentingnya hal ini. Seperti yang telah diuraikan, remaja merupakan tahap yang paling kritis.Keadaan ini membuat para remaja mengembangkan potensi dirinya dan memanfaatkan ilmu pengetahuan serta sarana tekhnologi yang ada seperti, komputer, internet, dan telepon seluler atau handphone. Perkembangan ilmu pengetahuan dan teknologi yang demikian pesat selain menimbulkan dampak positif juga menimbulkan dampak negatif khususnya bagi remaja yang menerima perkembangan tekhnologi ini biasanya disebut korban perkembangan ilmu pengetahuan dan teknologi (Yuniarto, 2008).

Meningkatnya ilmu tekhnologi tidak menurunkan angka kenakalan remaja, melainkan sebaliknya. Keadaan ini dapat dilihat berdasarkan laporan wartawan kompas Regina Rukmorini, dari 4,2 juta website porno yang beredar diseluruh dunia, sebanyak 100.000 website diantaranya memakai model remaja 
dengan rata-rata usia 18 tahun. Sebagian besar diantaranya, bahkan ditenggarai oleh remaja Indonesia.

Data survey yang pernah dilakukan pada beberapa sekolah SMA di Kota Bogor sebanyak 10 persen pelajar SLTA di Kota Bogor telah melakukan seks bebas. Rata-rata mereka pernah berhubungan intim satu kali dengan lawan jenisnya. Berbagai penelitian yang telah dilakukan tersebut, maka dapat dikatakan bahwa kemungkinan akibat dari kurangnya pengetahuan seks bebas dan informasi yang kurang tepat tentang seksual.

Hal ini dapat dilihat dengan adanya fenomena video porno pelajar yang telah tersebar luas memang sudah tidak asing lagi di Indonesia. Hampir semua remaja pernah menonton video porno ini yang sering mereka nikmati melalui situs porno internet, televisi, VCD, DVD, majalah dewasa, buku kemasutra yan terjual bebas di toko-toko buku besar. Hampir semua remaja yang mengaku pernah menonton video porno, lebih sering menggunakan telepon selular atau handphone. Yang dilengkapi dengan fasilitas kamera, video, bluetooth, infrared, bahkan juga situs internet, mereka juga mengaku mendapatkan rekaman video porno itu dari sesama teman mereka yang mereka transfer atau kirim dengan menggunakan layanan GPRS-MMS (pesan gambar), Bluetooth, infrared, dan sebagainya (Yuniarto, 2008).

Fenomena video porno ini pernah menggeparkan Indonesia pada tahun 2001 dimana beredarnya video porno yang berjudul Bandung Lautan Api (BLA). Bukan hanya video porno saja yang tersebar luas diberbagai situs, melainkan juga adanya foto-foto vulgar yang dibuat atau dilakukan oleh para pelajar itu sendiri, yang saat ini semakin banyak tersebar luas diberbagai situs internet. Peristiwa ini dapat di gunakan sebagai salah salah satu bukti bahwa media massa sangat erat hubungannya terhadap perkembangan sikap dan perilaku seksual remaja.

Selain itu seks bebas juga dapat mengancam masa depan remaja terutama pada bidang pendidikan. Hampir seluruh sekolahsekolah yang rata-rata tingkat SMA (Sekolah Menengah Atas) mengaku setiap tahunnya terpaksa mengeluarkan muridnya dari sekolah karena dianggap bersalah. Permasalahan ini merupakan kasus yang berhubungan dengan tindak pidana seperti pemakaian narkoba, tawuran yang mengancam jiwa, bahkan seks bebas yang menyebabkan kehamilan di luar nikah dan terkadang berujung dengan aborsi (Lummonan, 2004).

Saat ini tingkat pendidikan seseorang menjadi prioritas utama dalam mencari pekerjaan, hal ini dilakukan hanya untuk demi mendapatkan taraf hidup yang lebih layak. Jika dihubungkan dengan peristiwa di atas maka perilaku seks bebas pada remaja harus cepat di tanggulangi. Hal ini di lakukan bukan semata untuk para remaja itu sendiri, tetapi demi negara tercinta ini. Karena masa depan negara ini ada ditangan remaja kita.

Dalam masalah ini untuk menekan jumlah pelaku seks bebas terutama di kalangan remaja bukan hanya membentengi diri mereka dengan unsur agama yang kuat, juga dibarengi dengan pendamping orang tua dan selektivitas dalam memilih teman-teman. Karena ada kecenderungan remaja lebih terbuka kepada teman dekatnya ketimbang orang tua mereka sendiri (Soetjiningsih, 2003).

Penyakit Menular Seksual (PMS) dapat terjadi ditingkat remaja khusunya yang masih duduk di bangku sekolah, dimana mereka tenaga kesehatan mempunyai peranan penting serta dapat bekerja sama dengan pihak sekolah dalam menyumbangkan pengetahuan serta memberikan penyuluhan tentang kesehatan reproduksi dikalangan remaja, namun bukan pendidikan seks secara vulgar, melainkan pendidikan seperti: tentang organ reprodusi, bahaya akibat pergaulan bebas, seperti penyakit menular seksual dan sebagainya. Dengan demikian di harapkan para remaja ini bisa terhindar dari percobaan seks bebas.

SMA Negeri 4 Baubau merupakan salah satu SMA yang terletak di wilayah Kota Baubau Jalan Betoambari No.73 dan juga termasuk sekolah yang banyak di minati oleh remaja. Selain itu daerah tersebut terdapet beberapa SMA sehingga tidak menutup kemungkinan akan berdampak pada pergaulan bebas. Dan peneliti mendapatkan informasi dari guru BK (Bagian Kesiswaan) SMA Negeri 4 Baubau bahwa di sekolah pernah terjadi beberapa kasus hamil di luar nikah yang di alami oleh siswa perempuan yang masih berstatus pelajar aktif sehingga siswa tersebut memilih untuk keluar dari sekolah. Hal ini merupakan kejadian buruk bagi sekolah dan perluh dilakukan antisipasi agar kejadian yang sama tidak terulang kembali. Kurangnya pengetahuan siswa tentang seks pranikah dan banyaknya siswa dari luar kota, sehingga ada 
beberapa siswa yang pergaulannya bebas, ini juga merupakan salah satu penyebab siswa tidak perawan lagi (Profil SMA Negeri 4 Baubau).

Dengan demikian peneliti tertarik untuk melakukan penelitian mengenai Hubungan Pengetahuan Remaja dan Motivasi Guru dengan Perilaku Seks Bebas di SMA Negeri 4 Baubau.

\section{BAHAN DAN METODE}

\section{Desain dan Variabel Penelitian}

Jenis penelitian ini adalah survei analitik, dengan mengunakan rancangan penelitian cross sectional study untuk mengetahui hubungan pengetahuan remaja dan motivasi guru dengan perilaku seks bebas di SMA Negeri 4 Baubau Tahun 2013. Variabel penelitian yaitu perilaku seks bebas sebagai variabel dependen. Pengetahuan dan motivasi guru sebagai variabel independen.

\section{Lokasi dan Waktu Penelitian}

Tempat penelitian ini dilaksanaan di SMA Negeri 4 Baubau dan dilaksanakan pada bulan September Tahun 2013.

\section{Populasi, Sampel dan Sampling}

Populasi dalam penelitian ini adalah seluruh siswa SMA Negeri 4 Baubau pada Tahun Ajaran 2013 dengan jumlah 745 orang. Dalam penelitian ini, sampel diambil dengan metode simple random sampling, yaitu pengambilan sampel secara acak. Jadi, jumlah siswa di SMA Negeri 4 Baubau yang menjadi sampel dalam penelitian ini adalah sebanyak 88 orang.

\section{Pengumpulan Data}

Teknik pengumpulan data dalam penelitian ini ada dua yaitu jenis data primer yang diperoleh melalui wawancara langsung kepada responden dengan menggunakan bantuan kuesioner.

Data yang diperoleh dari instansiinstansi lain yang berkaitan dengan objek penelitian dan jenis data sekunder adalah data Profil dan Laporan SMA Negeri 4 Baubau.

\section{Analisis Data}

Analisis univariat digunakan untuk mengetahui distribusi dan persentase dari tiap variabel bebas dengan variabel terikat. Analisis bivariat merupakan analisis dua variabel yang dilakukan untuk menguji ada tidaknya hubungan antara satu variabel bebas dan variabel terikat dengan menggunakan uji Chi Square.

\section{HASIL PENELITIAN \\ Analisis Variabel Penelitian}
Tabel 1. Distribusi Perilaku Seks Bebas, Pengetahuan dan Motivasi Guru

\begin{tabular}{lcc}
\hline \multicolumn{1}{c}{ Variabel } & n & \% \\
\hline Perilaku Seks Bebas & & \\
$\quad$ Cukup & 60 & 68,2 \\
$\quad$ Kurang & 28 & 31,8 \\
Pengetahuan & & \\
$\quad$ Baik & 70 & 79,5 \\
$\quad$ Buruk & 18 & 20,5 \\
Motivasi Guru & & \\
$\quad$ Baik & 58 & 65,9 \\
$\quad$ Buruk & 30 & 34,1 \\
\hline
\end{tabular}

Pada tabel 1 menunjukan bahwa, dari 88 responden menurut perilaku seks bebas, yang menyatakan perilaku seks cukup yaitu berjumlah 60 responden $(68,2 \%)$, dan yang yang menyatakan perilaku seks bebas kurang berjumlah 28 responden (31,8\%). Menurut pengetahuan siswa, yang menyatakan pengetahuan siswa baik yaitu berjumlah 70 responden $(79,5 \%)$, dan yang yang menyatakan pengetahuan siswa buruk berjumlah 18 responden (20,5\%). Menurut motivasi guru, yang menyatakan motivasi guru baik yaitu berjumlah 358 responden $(65,9 \%)$, dan yang yang menyatakan motivasi guru buruk berjumlah 30 responden $(34,1 \%)$.

Pada tabel 2 menunjukkan bahwa, dari 88 responden berdasarkan pengetahuan dengan perilaku seks bebas, yang menyatakan pengetahuan siswa baik dengan perilaku seks cukup berjumlah 54 orang $(77,1 \%)$ dan pengetahuan siswa baik dengan perilaku seks bebas kurang berjumlah 16 (22,9\%). Sedangkan yang menyatakan pengetahuan siswa buruk dengan perilaku seks cukup yaitu 6 responden $(33,3 \%)$ dan yang menyatakan pengetahuan siswa buruk dengan perilaku seks kurang berjumlah 12 orang $(66,7 \%)$. Hasil penelitian juga menunjukkan bahwa, dari 88 responden berdasarkan motivasi guru dengan perilaku seks bebas, yang menyatakan motivasi guru baik dengan perilaku seks cukup berjumlah 49 orang $(84,5 \%)$ dan motivasi guru baik dengan 
perilaku seks bebas kurang berjumlah 9 $(15,5 \%)$. Sedangkan yang menyatakan motivasi guru buruk dengan perilaku seks cukup yaitu 9 responden $(36,7 \%)$ dan yang menyatakan motivasi guru buruk dengan perilaku seks kurang berjumlah 19 orang $(63,3 \%)$.

Tabel 1. Hubungan Perilaku Seks Bebas dengan Pengetahuan dan Motivasi Guru di SMA Negeri 4 Baubau

\begin{tabular}{|c|c|c|c|c|c|c|c|}
\hline \multirow{3}{*}{ Variabel Penelitian } & \multicolumn{4}{|c|}{ Perilaku Seks Bebas } & \multirow{2}{*}{\multicolumn{2}{|c|}{ Jumlah }} & \multirow{3}{*}{ X2 (p) } \\
\hline & \multicolumn{2}{|c|}{ Cukup } & \multicolumn{2}{|c|}{ Kurang } & & & \\
\hline & $\mathbf{n}$ & $\%$ & $\mathbf{n}$ & $\%$ & $\mathbf{n}$ & $\%$ & \\
\hline \multicolumn{8}{|l|}{ Pengetahuan } \\
\hline Baik & 54 & 77,1 & 16 & 22,9 & 70 & 100 & 10.728 \\
\hline Buruk & 6 & 33,3 & 12 & 66,7 & 18 & 100 & 0,001 \\
\hline Jumlah & 60 & 68,2 & 28 & 31,8 & 88 & 100 & \\
\hline \multicolumn{8}{|l|}{ Motivasi Guru } \\
\hline Baik & 49 & 84,5 & 9 & 15,5 & 58 & 100 & 18,693 \\
\hline Buruk & 11 & 36,7 & 19 & 63,3 & 30 & 100 & 0,000 \\
\hline Jumlah & 60 & 68,2 & 28 & 31,8 & 88 & 100 & \\
\hline
\end{tabular}

\section{PEMBAHASAN}

Pengetahuan merupakan hasil dari tahu, dan ini terjasi setelah orang melakukan penginderaan terhadap suatu objek tertentu. Pengetahuan yang baik didukung oleh tingkat pengetahuan orang tua yang baik dalam memberikan informasi (Notoatmodjo, 2005).

Hasil penelitian menunjukkan bahwa, dari 88 responden berdasarkan pengetahuan dengan perilaku seks bebas. Yang menyatakan pengetahuan siswa baik dengan perilaku seks cukup berjumlah 54 orang $(77,1 \%)$ dan pengetahuan siswa baik dengan perilaku seks bebas kurang berjumlah 16 (22,9\%). Dari hasil dapat dilihat bahwa banyak siswa yang mempunyai pengetahuan baik tentang seks bebas. Siswa mengetahuinya melalui orang tua, guru agama, dan media sosial seperti televisi, majalah, internet.

Hasil penelitian juga menunjukkan bahwa yang menyatakan pengetahuan siswa buruk dengan perilaku seks cukup yaitu 6 responden $(33,3 \%)$ dan yang menyatakan pengetahuan siswa buruk dengan perilaku seks kurang berjumlah 12 orang $(66,7 \%)$. Masih terdapatnya siswa yang berpengatahuan buruk, hal ini disebabkan orang tua siswa yang selalu membimbing dan mengawasi anaknya agar tidak kenal dengan seks bebas. Masih terdapatnya siswa yang berpengahuan buruk dan dan berperilaku seks, hal ini disebabkan rasa ingin tahu anak yang cukup besar tentang seks bebas, sehingga ingin mencoba dan melakukan seks bebas. Kurangnya pengawasan orang tua dan pemahaman agama anak sehingga anak bergaul bebas dan melakukan seks bebas dengan lawan jenis atau teman sebayanya.

Hal ini sesuai dengan pendapat Syafruddin (2008), pengetahuan yang setengahsetangah justru lebih berbahaya daripada tidak tahun sama sekali. Pembentukan pengetahuan sendiri dipengaruhi oleh faktor internal yaitu cara individu dalam menanggapi pengetahuan tersebut dan eksternal yang merupakan stimulus untuk mengubah pengetahuan tersebut menjadi lebih baik lagi (Syafrudin, 2008).

Hasil penelitian diatas sejalan dengan penelitian yang dilakukan oleh Ririn (2009) pada Remaja SMA di Surakarta, hasil penelitian menunjukkan bahwa terdapat hubungan antara pengetahuan dengan perilaku seks pranikah remaja dengan nila $p=0,002$. Hasil penelitian tersebut menunjukkan bahwa responden mempunyai pengetahuan baik yaitu 94 responden $(82,5 \%)$, dan yang menyatakan pengetahuan tidak baik 20 responden $(17,5 \%)$ (Ririn, D., 2009).

Hasil penelitian menunjukkan bahwa, dari 88 responden berdasarkan motivasi guru dengan perilaku seks bebas, yang menyatakan motivasi guru baik dengan perilaku seks cukup berjumlah 49 orang (84,5\%). Dari hasil penelitian dapat dilihat bahwa guru telah 
memberikan motivasi tentang perilaku seks bebas, khususnya guru Agama di sekolah. Motivasi guru sangat penting dalam memberikan pengetahuan tentang seks bebas, terutama tentang pemahaman Agama.

Hasil penelitian juga mennyatakan bahwa motivasi guru baik dengan perilaku seks bebas kurang berjumlah $9(15,5 \%)$. Sedangkan yang menyatakan motivasi guru buruk dengan perilaku seks cukup yaitu 9 responden $(36,7 \%)$ dan yang menyatakan motivasi guru buruk dengan perilaku seks kurang berjumlah 19 orang $(63,3 \%)$. Perilaku seks kurang, pada siswa, karena di rumah orang tua mereka dibimbing dan ditekankan untuk tidak mengenal seks dan memberikannya pemahaman agama. Dan masih terdapatnya guru yang memberikan motivasi, hal ini disebabkan guru mata pelajaran selain agama, bisanya tabu untuk membicarakan seks di depan siswa, dan kurang memberikan pemahaman dan pelajaran tentang seks bebas.

Guru dalam memberikan informasi kesehatan reproduksi kurang, kurangnya motivasi guru untuk memberikan informasi kesehatan resproduksi dan seksualitas disebabkan oleh kurang perhatiannya guru kepada siswa dan masih menganggap tabu membicarakan kesehatan reproduksi. Apabila guru mempunyai pengetahuan yang cukup mendalam tentang kesehatan reproduksi remaja lebih yakin dan tidak merasa cangung untuk membicarakan yang berhubungan dengan masalah seks bebas.

Hasil penelitian diatas sejalan dengan penelitian yang dilakukan oleh Ririn (2009) pada Remaja SMA di Surakarta, hasil penelitian menunjukkan bahwa terdapat hubungan antara motivasi/peran keluarga dengan perilaku seks pranikah remaja dengan nila $p=0,002$. Hasil penelitian tersebut menunjukkan bahwa responden yang mempunyai motivasi/peran keluarga baik yaitu 77 responden $(67,5 \%)$, dan yang menyatakan motivasi/peran keluarga tidak baik 37 responden (32,5\%) (Ririn, D., 2009).

\section{KESIMPULAN DAN SARAN}

Berdasarkan hasil penelitian dapat disimpulkan bahwa ada hubungan antara pengetahuan siswa dengan perilaku seks bebas $\left(X^{2}=10,728\right.$, $\mathrm{p}=0,001)$, ada hubungan antara pengetahuan siswa dengan perilaku seks bebas $\left(X^{2}=138,692\right.$, $\mathrm{p}=0,000)$. Disarankan siswa dapat meningkatkan pengetahuan tentang seks bebas, pemahaman Agama, dengan mencari informasi yang baik dan akurat serta dapat memilih teman yang baik agar tidak berpengaruh terhadap perilaku seks bebas. Guru dapat memotivasi dengan memberikan pengetahuan tentang seks bebas, dan pemahaman Agama serta memberikan informasi yang baik dan bertanggungjawab agar siswa tidak salah dalam mendapatkan informasi yang dapat mempengaruhi perilaku siswa.

\section{DAFTAR PUSTAKA}

Sarlito. (2011). Perilaku Seks Remaja. http://elfarid.multiply.com/journal/item/3 06 Diakses 7 Januari 2009

Subhakti. (2009). Pengertian Remaja. http://www.google.com. Diakses Maret 2013

Yuniarto. (2008). Perilaku Kenakalan Remaha Pengaruh Lingkungan Keluarga dan Lingkungan Teman. http://rudict. com/PPS702-ipb/1101/HERIAEN.html.

Lummonan. (2004). Psikologi Perkembangan Remaja. Bandung: Ghalia Indonesia.

Soetjiningsih. (2003). Cara Menghindari Seks Dikalangan Remaja. http://www. blogspot.com/2007.

Profil SMA Negeri 4 Baubau.

Notoatmodjo. (2005). Pendidikan dan Perilaku Kesehatan. Rineka Cipta., Jakarta

Syafrudin. (2008). Remaja dan Hubungan Seksual Pranikah. http://id.shvoong. com/medicine- and- health/1799376. Diakses pada tanggal 21 Januari 2009.

Ririn, Damarsih. (2009). Faktor yang Mempengaruhi Perilaku Seks Pranikah pada Remaja SMA di Surakarta. FKM, Universitas Muhammadiya Surakarta. 